\title{
Introduced blackbirds and song thrushes: useful substitutes for lost mid-sized native frugivores, or weed vectors?
}

\author{
Archie E. T. MacFarlane, Dave Kelly* and James V. Briskie \\ School of Biological Sciences, University of Canterbury, Private Bag 4800, Christchurch 8140, New Zealand \\ *Author for correspondence (Email: dave.kelly@canterbury.ac.nz) \\ Published online: 7 December 2015
}

\begin{abstract}
The New Zealand avifauna has declined from human impacts, which might leave some larger-seeded native plants vulnerable to dispersal failure. We studied fruit dispersal in a lowland secondary forest near Kaikoura, where the only remaining native frugivores are relatively small (silvereye Zosterops lateralis, and bellbird Anthornis melanura). We tested whether two larger exotic frugivores (blackbird Turdus merula and song thrush T. philomelos) dispersed native plants with seeds too large for the two smaller native frugivores. Diet breadth was measured by identifying seeds in the faeces of 221 mist-netted birds, and by observations of birds foraging. We then compared the plant species dispersed to the range of locally available fruits. All four bird species had varied diets (6-9 plant species per bird species) that differed significantly, although Coprosma robusta was always the most-eaten fruit. As predicted, the maximum fruit size eaten was larger for exotic birds (11.3 mm diameter) than natives (7.4-7.7 mm diameter), but all birds ate mainly smaller fruits. However, 7/21 fruiting plant species were not seen to be dispersed by any species, and the chance of being undispersed was independent of fruit size. Blackbirds and song thrushes jointly dispersed all four woody weeds with fruits $>7.5 \mathrm{~mm}$ diameter, but neither of the two similar-sized native plants. Although the two species of exotic birds dispersed some native plants, our study suggests that their net effect is negative through facilitating the spread of invasive weeds. Studies evaluating the contribution of exotic frugivores to novel plant communities need to distinguish potential effects (what the frugivores might be capable of doing) from actual effects (what the frugivores are observed doing).
\end{abstract}

Keywords: exotic seed dispersers, frugivory, gape limitations, Kowhai Bush, seed dispersal

\section{Introduction}

Frugivory is a key mutualistic service on which many plant species depend for dispersal (Snow 1971; Howe 1977; Thompson \& Willson 1979). Worldwide, birds play an exceptionally important role as dispersal vectors for fruiting species (Morton 1973; Clout \& Hay 1989; Bakker et al. 1996; Levey et al. 2002; Wenny et al. 2011). In New Zealand, birds historically and presently perform the majority of fruit dispersal services (Clout \& Hay 1989; Lee et al. 1991; Webb \& Simpson 2001; Thorsen et al. 2009; Thorsen et al. 2011).

Human colonisation of New Zealand over the past 1000 years has resulted in the extinction or decline of many native vertebrates (McGlone 1989; Holdaway 1999; Clout \& Lowe 2000; Thorsen et al. 2011). The effect of this loss on seed dispersal is unclear. Thorsen et al. (2011) estimated that 57\% of volant and $80 \%$ of flightless frugivorous birds have become extinct in New Zealand since human arrival, but many of these lost species were apparently either minor frugivores or the extent of their frugivory was unknown. Atkinson and Millener (1991) reported that none of the important volant frugivores have gone extinct, although several species (e.g. kōkako Callaeas cinerea, and saddleback Philesturnus carunculatus) have greatly reduced ranges and two extinct birds (huia Heteralocha acutirostris and piopio Turnagra capensis), classed by Atkinson and Millener (1991) as insectivores, may also have made important contributions to seed dispersal. Overall, it seems that only a few important frugivores have become globally or functionally extinct, and several species of native frugivorous birds still remain.
Whether the surviving native frugivores manage to maintain dispersal services for the full range of native plants is not well understood. A recent quantitative summary of visitors to native fruiting plants (Kelly et al. 2006) found that fruit dispersal in New Zealand is largely dependent on four birds: endemic kererū (Hemiphaga novaeseelandiae), tūī (Prosthemadera novaeseelandiae), and bellbird (Anthornis melanura), and the recently arrived native silvereye (Zosterops lateralis). However, in many forests only two or three of these bird species are present (Robertson et al. 2007), and the kererū is the only one able to swallow fruits over $15 \mathrm{~mm}$ diameter (Kelly et al. 2010). With so few native species, mutualism disruption is still a risk (Sekercioglu et al. 2004).

Although native birds have declined, many exotic bird species have been introduced into New Zealand since 1840 (Green 1997; Heather \& Robertson 1998). Somenaturalised bird species are now abundant. Six of the ten most widely distributed birds in the latest breeding bird atlas (Robertson et al. 2007) were exotics, including three important frugivores: European blackbird (Turdus merula), song thrush (T. philomelos), and European starling (Sturnus vulgaris). However, the contribution of exotics to seed dispersal is unclear. In urban Wellington, blackbirds were reported to be a common and important frugivore (Burns 2012; Garcia et al. 2014). In contrast, in a review of bird visitors to many different native fruiting plants, exotic birds together accounted for only $5 \%$ of frugivore visits (Kelly et al. 2006). Lord et al. (2002) said the extent to which song thrushes and blackbirds were replacing lost dispersers was uncertain as they appeared to preferentially consume the fruit of exotic plants. Williams and co-workers have also shown that blackbirds and thrushes can have negative effects 
through assisting in the spread of exotic weeds (Williams \& Karl 1996; Williams 2006; Williams et al. 2010).

Despite evidence that introduced birds are inefficient dispersers for native vegetation, they may maintain dispersal when few native birds are available (Aslan et al. 2012). For example, the Hawaiian Islands have lost almost all of their native frugivores (Foster \& Robinson 2007), but gained many introduced bird species (Stone \& Anderson 1988). Most common understory plants in Hawaiian rainforests now depend on introduced birds for dispersal (Foster \& Robinson 2007).

The objective of this study was to estimate the contribution to fleshy-fruited seed dispersal by frugivorous birds in Kowhai Bush, one of the largest fragments of lowland regenerating native forest in the Kaikoura area, New Zealand. At this site, we never observed kererū and very rarely observed tūî (also see Hunt \& Gill 1979), but there were two commonly observed native smaller frugivores (bellbird [26-34 g mean body mass $]$ and silvereye $[13 \mathrm{~g}]$ ), and two common introduced larger frugivores (blackbird [90 g] and song thrush [70 g]). This assemblage makes Kowhai Bush an ideal place to study dispersal of fruiting plants by native and introduced birds. Specifically, we asked: (1) Which species of native and exotic fruiting plants are eaten by each frugivore? (2) Are any fruiting plants in Kowhai Bush not visited by frugivores? (3) Does frugivore gape size prevent some bird species from feeding on plant species with large fruit? (4) Do introduced blackbirds and song thrushes act as successful replacements for lost mid-sized native frugivorous birds?

\section{Methods}

Kowhai Bush is a 240-ha regenerating native forest near Kaikoura owned and managed by Environment Canterbury Regional Council. It is surrounded by pastoral land. All observations were carried out in the south-east of the reserve $\left(173^{\circ} 36.96^{\prime} \mathrm{E}, 42^{\circ} 22.62^{\prime} \mathrm{S}, 60-80 \mathrm{~m}\right.$ elevation a.s.1.) near Schoolhouse Road. The forest interior of Kowhai Bush is a flood-induced patchwork of successional stages of differing age and species composition. The forest canopy is 5-12 $\mathrm{m}$ high and dominated by kānuka (Kunzea ericoides) and mānuka (Leptospermum scoparium). A narrow strip of kānuka/broadleaf successional forest with frequent Melicytus ramiflorus and Pseudopanax arboreus covers river gravels on the north-eastern side. Along the eastern margins, large areas have extensive understory invasion by introduced barberry (Berberis glaucocarpa) and hawthorn (Crataegus monogyna). A fuller description of the vegetation of Kowhai Bush is given in Dobson (1979).

\section{Mist netting and data collection}

Faecal samples and gape-size measurements were collected from mist-netted birds. Mist netting was conducted from 1 March to 31 May 2011, when most species were fruiting. The only fruiting plant encountered in the site that ripens later was invasive European ivy (Hedera helix). Although Hunt and Gill (1979) recorded Mahonia aquifolium, Leycesteria formosa and Rubus fruticosus as fruiting later than May in areas of Kowhai Bush, we did not observe any of these species in our immediate study area. Nets were erected for 16-20 days each month and were placed in a variety of sites, including forest margins, clearings in the forest, or beneath the forest canopy. Netting was done in both morning (0730-1300 h) and afternoon
$(1300-1730 \mathrm{~h})$ periods. A total of four nets with $38 \mathrm{~mm}$ mesh were suspended between self-supporting poles $3.3 \mathrm{~m}$ tall. They were checked every 10-15 minutes to remove entangled birds. Nets were set up in one area for a maximum of 5 days before being moved to a new location at least $50 \mathrm{~m}$ away. Moving the nets regularly was designed to sample across the range of different habitat types, to increase the chances of observing seeds from plants with a locally patchy distribution, to reduce the chances of re-sampling the same individual birds (which were unbanded), and to reduce the likelihood that birds became wary of the nets, which helped increase catch rates. To increase catch rates both audio and visual decoys were used to lure birds into the nets.

To collect faeces, plastic sheets were placed under each of the nets. The sheets were $1 \mathrm{~m}$ wide and extended the length of the nets. When birds became entangled they normally defecated onto these sheets. Faecal samples were then collected off the sheets and the bird species was noted. If a bird had not defecated onto the plastic sheet it was placed in a paper or cloth bag for 5-10 minutes and faeces collected from the bag. If the bird still had not defecated, it was released. For each bird captured, sex and species was noted, and horizontal gape width was measured at the base of the bill using digital callipers following Hulsman (1981) and Kelly et al. (2010). Faecal samples were stored in $70 \%$ alcohol before being examined under a dissecting microscope. Seeds were then identified to plant species with the aid of a reference collection of seeds from fruit collected in Kowhai Bush during the study.

\section{Direct feeding observations and fruit observations}

Throughout the study period, a series of opportunistic observations on foraging birds was made to determine whether other plant species were being consumed that were not recorded in faecal samples. While waiting for birds to enter the mist-nets the observer would scan surrounding vegetation for foraging birds. When a bird was observed feeding on fruit, the date, identity of the bird and plant species were recorded. We assumed that any fruits observed eaten or found in faeces were dispersed.

Fruit samples were collected from 5-10 plants of each fleshy-fruited species in Kowhai Bush and were used to create a seed reference collection and to measure the diameter of fruit for comparison with gape size. The minimum diameter of fruit in each species, which sets the limit of swallowing ability (Kelly et al. 2010), was measured on 25 fruits from each species (except Leucopogon fasciculatus, Pseudowintera colorata, Muehlenbeckia australis and Cordyline australis, for which we were unable to collect fruit). Fruits of Pittosporum tenuifolium were also not measured since this species produces a dry capsule that opens to expose seeds in pulp, which the birds consume. These five species are not included in Figure 1 , but to sort them by size (Table 1) we used unpublished fruit size data (Janice Lord, pers. comm.) and an estimate of seed size for P. tenuifolium from Webb and Simpson (2001).

To determine the relative abundance of different fruiting plant species at the study site, the abundance of each species was ranked on a six-point subjective scale, based on the approximate number of plants expected per $50 \times 50 \mathrm{~m}$ quadrat: (1) plants not in Kowhai Bush but present within $0.25 \mathrm{~km}$ of the site, (2) very uncommon in Kowhai Bush (1-2 plants), (3) uncommon (3-6 plants), (4) patchy (6-10 plants, often clumped together), (5) common (10-15 plants), and (6) abundant (15+ plants).

\section{Analysis}

To determine whether the types of fruit eaten varied among 
Table 1. Fruiting plants in Kowhai Bush recorded as being fed on by birds, either from faecal samples (\% identified seeds for that species) or from field observations $(+)$. X indicates fruits with mean diameters ('Fruit diam.') more than $1.6 \times$ gape size, which the birds are unlikely to be able to eat (although silvereyes have been reported eating $R$. scandens).

\begin{tabular}{|c|c|c|c|c|c|c|}
\hline Plant species & $\begin{array}{c}\text { Plant } \\
\text { abundance\# }\end{array}$ & $\begin{array}{l}\text { Fruit diam. } \\
\quad(\mathrm{mm})\end{array}$ & Silvereye & Bellbird & Song thrush & Blackbird \\
\hline Leucopogon fasciculatus & 2 & 3.0 & 0 & 0 & 0 & 0 \\
\hline Pseudopanax arboreus & 5 & 3.1 & 16.6 & 0 & 1.9 & 0 \\
\hline Cordyline australis & 2 & 3.7 & 0 & 0 & 0 & 0 \\
\hline Pittosporum tenuifolium & 4 & 3.7 & 0.9 & 0 & 0 & 0 \\
\hline Coprosma propinqua & 3 & 3.7 & 5.9 & 1.9 & 0 & 0 \\
\hline Myrsine australis & 4 & 3.8 & 0 & 0 & 0 & 0 \\
\hline Coprosma rhamnoides & 5 & 4.2 & 7.3 & 5.6 & 1.9 & 0 \\
\hline Melicytus ramiflorus & 5 & 4.4 & 5.2 & 0 & 0 & 0 \\
\hline Muehlenbeckia australis & 4 & 5.0 & 7.5 & 0.9 & 0 & 0.7 \\
\hline Coprosma robusta & 6 & 5.1 & 54.2 & 90.4 & 53.8 & 80.6 \\
\hline Ileostylus micranthus & 2 & 5.4 & 0.2 & 1.2 & 0 & 0 \\
\hline Pseudowintera colorata & 2 & 5.7 & 0 & 0 & 28.8 & 0 \\
\hline Corokia cotoneaster & 3 & 5.8 & 0 & 0 & 0 & 0 \\
\hline Myoporum laetum & 3 & 6.1 & 0 & 0 & 0 & 0 \\
\hline Coprosma grandifolia & 3 & 7.4 & 0 & + & 0 & 0 \\
\hline Berberis glaucocarpa $*$ & 5 & 7.7 & 2.3 & 0 & 13.5 & 13.4 \\
\hline Taxus baccata* & 4 & 9.1 & 0 & 0 & + & + \\
\hline Crataegus monogyna $*$ & 5 & 9.5 & $\mathrm{X}$ & 0 & 0 & + \\
\hline Hedycarya arborea & 4 & 10.8 & $X$ & 0 & 0 & 0 \\
\hline Ripogonum scandens & 4 & 10.8 & $X$ & 0 & 0 & 0 \\
\hline Vitis vinifera $*$ & 1 & 11.3 & $\mathrm{X}$ & 0 & + & 5.2 \\
\hline Bird gape (mm) & & & 5.7 & 7.9 & 11.6 & 11.9 \\
\hline No. birds caught & & & 109 & 40 & 7 & 15 \\
\hline No. faecal samples & & & 94 & 36 & 7 & 14 \\
\hline$\%$ faeces with seeds & & & 95.7 & 100 & 71.4 & 71.4 \\
\hline No. seeds in faeces & & & 574 & 325 & 52 & 134 \\
\hline$\%$ native seeds/total & & & 97.7 & 100 & 86.5 & 81.3 \\
\hline
\end{tabular}

* indicates an exotic plant species

\# Plant abundance categories: $1=$ not at study site but within $250 \mathrm{~m} ; 2=$ very uncommon; $3=$ uncommon; $4=$ patchy; $5=$ common; $6=$ abundant (see Methods for more details).

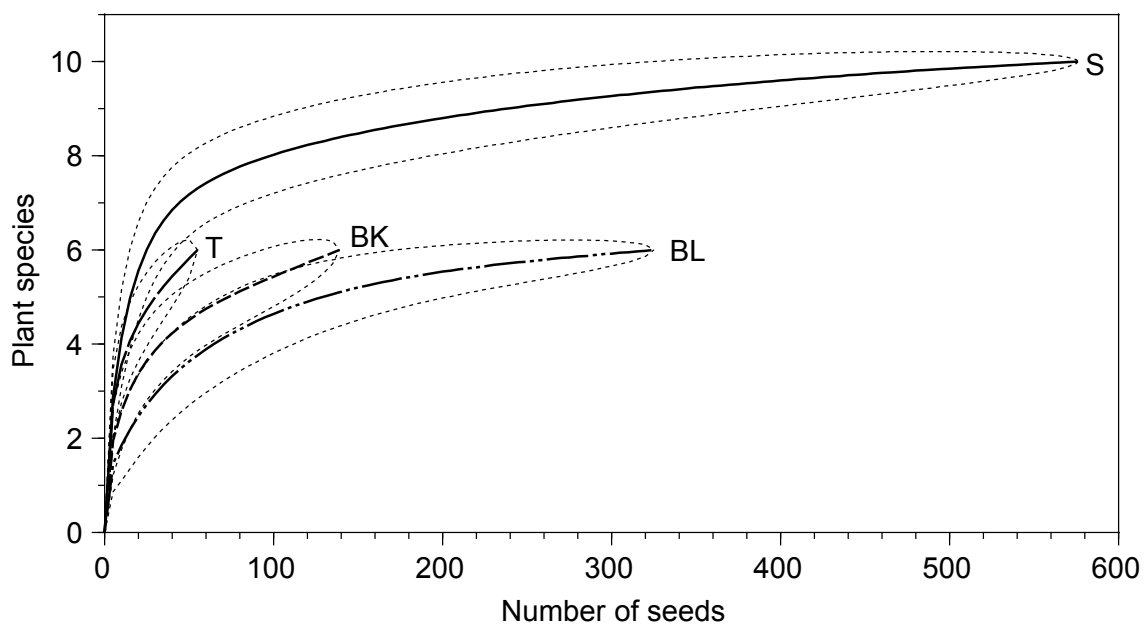

Figure 1. Rarefaction curves of the expected plant species richness (means \pm C.I.) with increasing numbers of individual seeds identified from bird faecal samples in Kowhai Bush. Species codes are S, silvereye; BL, bellbird; BK, blackbird; T, song thrush.

bird species, a $\chi^{2}$ test of independence was used. To allow for varying numbers of faecal samples among bird species, rarefaction curves were calculated for the total number of plant species dispersed by the four bird species in Kowhai Bush that were found to feed on fruit the most frequently (blackbird, song thrush, bellbird and silvereye). Rarefaction curves relate the number of plant (seed) species detected versus number of separate faecal samples or seeds examined (Heck Jr et al. 1975; Hyatt \& Casper 2000; Poulsen et al. 2001). To test whether plant abundance was associated with the chance of a plant being dispersed (based on our observations), we ran a one-way ANOVA on plant abundance scores comparing species that were dispersed ( $n=14)$ vs not dispersed $(n=7)$. To determine whether more common plants were likely to make up a bigger part of the diet, a regression tested plant abundance score against the mean $\%$ of diet (averaged across all four bird species, and counting plants not found in faecal samples but observed being eaten as $0.1 \%$ of the diet). Mean $\%$ of diet was log-transformed before analysis to improve normality. 


\section{Results}

A total of 21 potentially bird-dispersed plant species were observed fruiting in Kowhai Bush during the autumn (Table 1), of which 17 species were native. Eleven plant species were found in bird faecal samples, and an additional three species were seen being eaten in direct foraging observations. No evidence of bird dispersal was observed during this study for seven species of native fruiting plants (33\%; Table 1).

In total, 221 birds from 10 species were caught in mist nets and 183 faecal samples were collected. Four bird species had no seeds in any of their faecal samples (fantail Rhipidura fuliginosa, 24 birds and 14 faecal samples; grey warbler Gerygone igata 17 birds and 11 samples; chaffinch Fringilla coelebs 3 birds and 3 samples; New Zealand robin Petroica australis 1 bird and 1 sample). Two other species had some seeds in faeces but were caught too rarely to analyse (dunnock Prunella modularis, 3 birds, 3 samples, of which one contained seeds of Coprosma robusta, and brown creeper Mohoua novaeseelandiae, 2 birds, 2 samples, both containing seeds of Melicytus ramiflorus and/or Muehlenbeckia australis). The four main frugivore species produced 151 faecal samples (from 171 birds) of which 141 contained seeds (Table 1). A total of 1085 seeds were found in these faecal samples. All seeds were intact (not fragmented) and could be identified to species.

\section{Plant species in bird diets}

Although each bird species fed on between six and nine plant species, Coprosma robusta made up the majority of seeds for all four frugivorous species (Table 1). Nevertheless, there was still a significant difference between the expected and observed seed species among the four bird species $\left(\chi^{2}=279.3, \mathrm{df}=18\right.$, $P<0.001)$. Bellbirds had more C. robusta, and less Pseudopanax arboreus and Berberis glaucocarpa than expected. Silvereyes had relatively less C. robusta, but more Melicytus ramiflorus, Pseudopanax arboreus, and Muehlenbeckia australis, than expected. Blackbirds and song thrushes both had more Berberis glaucocarpa than expected, and song thrushes also carried many Pseudowintera colorata seeds.
Rarefaction curves were calculated to determine whether estimates of diet breadth were affected by the number of faecal samples collected. After allowing for sampling effort, silvereyes and song thrushes had slightly more diverse diets than bellbirds and blackbirds (Fig. 1). Predicted asymptotic total diet breadth was about 10 plant species for silvereyes and song thrushes, but only about six plant species for bellbirds and blackbirds.

\section{Gape size and limitations}

The size of consumed fruits was compared with bird gape size (Fig. 2) to determine whether diet might be restricted by gape limitations (Table 1). Birds have been reported to consume species with mean fruit width up to about 1.6 times the bird mean gape width (Kelly et al. 2010). Blackbirds had the largest gape of $11.9 \pm 0.04 \mathrm{~mm}$ (mean \pm C.I., $n=8$, range 11.6-12.4 $\mathrm{mm})$, with song thrushes slightly smaller $(11.6 \pm 0.24 \mathrm{~mm}$, $n=5$, range 10.9-12.3). This would allow both birds to eat all fruiting species at the site (Fig. 2). Bellbirds (7.9 \pm 0.01 $\mathrm{mm}, n=15$, range $5.6-8.8 \mathrm{~mm})$ and silvereyes $(5.7 \pm 0.001$ $\mathrm{mm}, n=27$, range $5-6.5 \mathrm{~mm}$ ) had smaller gapes. As a result, silvereyes are unlikely to be able to consume the largest four plant species (all $>1.6 \times$ gape size). Nonetheless, silvereyes did consume $B$. glaucocarpa (Table 1), confirming that birds can eat fruits somewhat larger than their gape (B. glaucocarpa is $1.35 \times$ larger than the silvereye mean gape). All four bird species consumed some fruits over $7 \mathrm{~mm}$ mean diameter. Although the smaller birds seemed to eat more small fruit (Table 1), mean fruit size (weighted by number of seeds found in faeces, counting ' + ' as $0.1 \%$ ) increased only slightly from silvereyes $(4.6 \mathrm{~mm})$ to bellbirds $(5.0 \mathrm{~mm})$, song thrushes $(5.6$ $\mathrm{mm})$ and blackbirds $(5.9 \mathrm{~mm})$. This lack of differences was probably because all birds ate a lot of small fruits, including abundant $C$. robusta.

\section{Undispersed plant species}

One-third of the fruiting plant species at Kowhai Bush were not seen to be dispersed by the birds in our study, although they probably have some dispersal occurring below our power

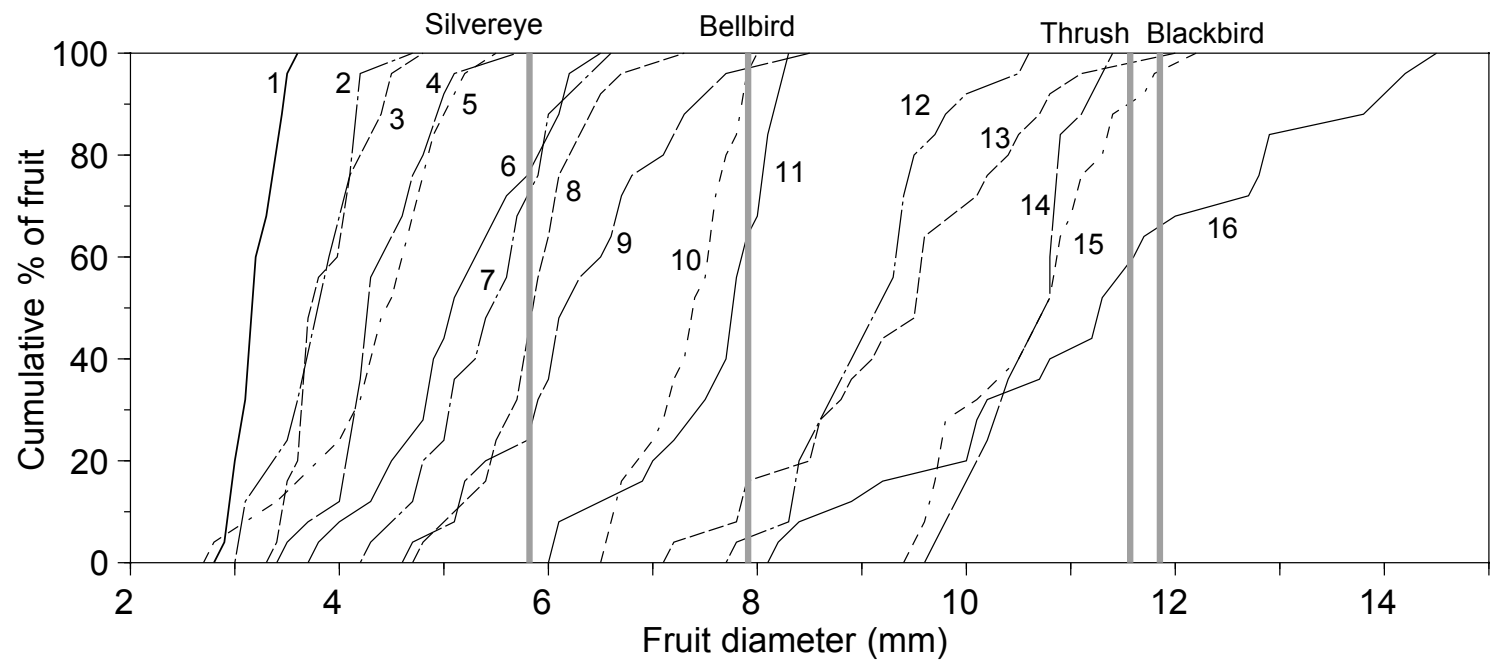

Figure 2. Distributions of cumulative fruit diameters for 16 of the fruiting plant species in Kowhai Bush, autumn 2011. The mean gape size for silvereye, bellbird, song thrush and blackbird are presented as vertical grey lines. Plant species: 1 Pseudopanax arboreus; 2 Myrsine australis; 3 Coprosma propinqua; 4 Coprosma rhamnoides; 5 Melicytus ramiflorus; 6 Coprosma robusta; 7 Ileostylus micranthus; 8 Corokia cotoneaster; 9 Myoporum laetum; 10 Coprosma grandifolia; 11 Berberis glaucocarpa; 12 Taxus baccata; 13 Crataegus monogyna; 14 Hedycarya arborea; 15 Ripogonum scandens; 16 Vitis vinifera. 
of detection. It is unlikely that this was due to unpalatability of these seven plant species, as all have been reported in the diet of at least one of the four bird species present at our site (Clout \& Hay 1989; Burrows 1994; O’Donnell \& Dilks 1994; Williams \& Karl 1996; Ferguson \& Drake 1999). Undispersed species included the two largest-fruited native species, three mid-range species, and two of the three smallest-fruited species (Table 1). There was no significant effect of fruit size on chance of being undispersed (three of the 11 smallest-fruited species were not dispersed vs four of the 10 largest-fruited species; Fisher exact test, $P=0.66)$. Mean fruit size also did not differ significantly between dispersed $(6.1 \mathrm{~mm})$ and undispersed $(6.3 \mathrm{~mm})$ species $\left(\mathrm{t}_{19}=0.15, P=0.88\right)$. Although there was no evidence of a lower chance of dispersal for larger-fruited species, it is noteworthy that among the six plants with fruits over $7.5 \mathrm{~mm}$ diameter, four were weedy exotics and all of these were dispersed (largely by exotic birds), whereas neither of the two large-fruited natives was observed to be dispersed by any birds (Table 1).

Plant abundance had only weak effects on frugivore diet choice. Mean plant abundance scores did not differ significantly between dispersed plants (mean score 3.9, $n=14$ ) and undispersed plants (mean 3.1, $n=7$; one way ANOVA, $\left.F_{(1,19)}=1.39, P=0.210\right)$. Plant abundance score was significant as a predictor of $\log ($ mean diet $\%+1)$ in a linear regression $\left(F_{(1,19)}=4.52, P=0.047\right)$, but this relationship was dependent on Coprosma robusta, which was an outlier that comprised by far the largest part of the diet of all bird species, and was one of the most abundant plants. When $C$. robusta was excluded the regression was not significant $\left(F_{(1,18)}=0.91, P=0.35\right)$. Among the largest-fruited plant species only, the two native species were as abundant as the three exotics, so the lack of dispersal of the native species cannot be explained by them being locally rare. The only really uncommon species among the five largest, Vitis vinifera, was the most-often dispersed of the five (Table 1).

\section{Discussion}

Fruit dispersal by birds in Kowhai Bush confirms some trends noted elsewhere in New Zealand. Our study confirms that primarily insectivorous birds, such as grey warblers, fantails and dunnocks, may act as occasional frugivores but make only a small contribution to fruit dispersal. In contrast, silvereyes and bellbirds were frequent and important frugivores (Kelly et al. 2006, 2010). We found both native and exotic birds ate mainly native fruits, but endemic birds usually ate few exotic plants compared to exotic birds, with silvereyes intermediate between the two groups (Williams \& Karl 1996). The fruit of Coprosma robusta was a large component of frugivore diets, both in Kowhai Bush and elsewhere (O'Donnell \& Dilks 1986; Williams \& Karl 1996). The key questions we set out to answer are whether there is a 'dispersal gap' for large-seeded native plants (Wheelwright 1985; Alcántara \& Rey 2003), and whether exotic birds are having a positive or negative effect in the system. Specifically, we ask (1) whether declines in native frugivores are now limiting dispersal of large-seeded plants; (2) whether exotic birds are helping disperse large-seeded plants; (3) whether exotic birds are increasing the dispersal of woody weeds; and (4) whether the net effect of exotic birds is positive or negative.

\section{Is there a dispersal gap, and are exotic birds filling it?}

The decline in the native frugivore fauna may have left a gap in the dispersal service for large-seeded native plants. Human impacts mean that Kowhai Bush no longer has four endemic large-bodied frugivores, which were probably previously present and would have been capable of dispersing larger fruits: piopio (extinct), kokako (lost from the South Island), saddleback (severely range-reduced), and kaka (Nestor meridionalis, range and density reduced). Of the four surviving nationally important frugivores, the two largest ( kererū and tūi ) are very rare at the site, although kererū remain common in nearby podocarp forests (e.g. Fyffe Palmer reserve $5 \mathrm{~km}$ to the north; DK pers. obs., and Blue Duck reserve $20 \mathrm{~km}$ to the north-east; Kelly et al. 2010). As a result, the only remaining important native frugivorous birds in Kowhai Bush are the two smallest species (bellbird and silvereye). Several native plants have fruits too large for silvereyes, and close to the upper size limit for bellbirds, including two species that were not seen to be dispersed (Hedycarya arborea and Ripogonum scandens) and two species (Elaeocarpus dentatus and Prumnopitys ferruginea) present in forest $4 \mathrm{~km}$ away at Mt Fyffe, which are not reported from Kowhai Bush (Dobson 1979).

Despite the reduction in the native frugivore community, we found little evidence for a conspicuous gap in seed dispersal. Across all plant species, larger-seeded plants were no more likely than small-seeded plants to be recorded as undispersed. The main determinants of whether dispersal was detected appear to be fruit attractiveness (apparently high for Coprosma robusta fruit, but low for Corokia cotoneaster fruit; Young 2012), and perhaps plant abundance. In our analyses plant abundance had a small and usually non-significant effect, but our measure of plant abundance was subjective. More quantitative measures of fruit abundance may show stronger effects of availability. Both song thrushes and blackbirds are large enough to potentially disperse all available native fruiting species in Kowhai Bush. Although we did not find seeds of either $H$. arborea or $R$. scandens in 21 faecal samples from blackbirds and song thrushes, both birds have been reported previously as feeding on these two species (Clout \& Hay 1989; Kelly et al. 2010). The same is true of bellbirds, which had none of these seeds in 36 faecal samples but have been reported elsewhere feeding on both $H$. aboreus and $R$. scandens (Kelly et al. 2010). Both kererū and tūī should be more likely to disperse larger-fruited species, and though rare at our study site, they could be occasional dispersers in Kowhai Bush. Without a more targeted study on the large-fruited native plants, we are unable to say whether any of the five potential dispersers (blackbird, song thrush, bellbird, kererū , and tūī ) are actually moving large-seeded native plants around.

There is little evidence either locally or nationally for dispersal failure in native fleshy-fruited plants (Young 2012). We did not directly measure fruit removal rates, but severe dispersal failure should be apparent through overripe fruit shrivelling on the plant or piles of undispersed fruit underneath parent trees. Neither was observed for any native plants in Kowhai Bush, although there were many shrivelled fruit seen on the weed Berberis glaucocarpa (MacFarlane 2012). As noted above, two large-seeded native trees (E. dentatus and $P$. ferruginea) are present at Mt Fyffe but absent in Kowhai Bush. However, both may be missing because the habitat in Kowhai Bush is unsuitable due to stony soils and frequent river disturbance (Dobson 1979), rather than because of dispersal failure. We cannot rule out dispersal failure in Kowhai Bush, but there is currently no evidence to support it in the native flora.

Kelly et al. (2010) reviewed 10 studies of dispersal rates throughout New Zealand and found only one case (Pittosporum 
crassifolium) where dispersal was clearly failing. Those studies included the large-seeded Beilschmiedia tawa $(15.5 \mathrm{~mm}$ mean fruit diameter), which over nine seasons at Blue Duck reserve, $20 \mathrm{~km}$ north-east of Kowhai Bush, was apparently well-dispersed with half the fruits under parent trees having been through a bird. Kererū were also frequently seen feeding on it. These authors found little evidence for dispersal being currently limited by a shortage of birds, and also no evidence that the larger-seeded plants were less well-dispersed (Kelly et al. 2010). Our findings are consistent with this conclusion.

\section{Is weed spread by exotic birds a problem?}

The dispersal of woody weeds by birds into regenerating forest is considered an important threat to New Zealand's indigenous forests (Timmins \& Williams 1991). Timmins and Williams (1991) listed 75 problem weeds, including a number offleshy-fruited trees, shrubs and lianas. Both C. monogyna and B. glaucocarpa were listed, and both have spread extensively through our study site. Within Kowhai Bush, the four exotic large-seeded plants are all weedy, and there are other weedy species in the area that would be troublesome should they become common, including Passiflora mollissima var tripartita (banana passionfruit), Hedera helix (common ivy), Mahonia aquifolium (Oregon grape), Leycesteria formosa (Himalayan honeysuckle) and Rubus fruticosus (blackberry).

Although both native and exotic birds move the seeds of weed species, there is evidence that exotics are more likely to do so. Bellbirds rarely include exotic fruits in their diet (Allen \& Lee 1992; O’Donnell \& Dilks 1994; Williams \& Karl 1996), and ate no exotics in our study, ignoring abundant B. glaucocarpa fruits. Blackbirds are considered one of the top dispersers of exotic fruiting plants in New Zealand (Williams \& Karl 1996). Fewer observations have been made of the foraging behaviour of song thrushes in New Zealand; however, they are considered one of the top three dispersers for adventive weeds introduced from England to New Zealand (Snow \& Snow 2011). In our study, song thrushes and blackbirds together were observed feeding on fruit from all four species of woody weeds.

\section{Do exotic frugivores provide a net benefit?}

The question of whether exotic species such as blackbirds and song thrushes might provide significant dispersal services for native plants, despite also dispersing invasive weeds, has been controversial. There is more information on blackbirds than song thrushes, although the two species probably behave similarly. It has been suggested that blackbirds could be an important disperser of large seeds in the absence of kererū (Williams 2006), a point reinforced by Burns (2012), who found that blackbirds in Zealandia Sanctuary (in urban Wellington) were the second most common visitor to fruit. Burns (2012) argued that blackbirds might 'help to make the best of a bad situation' after native frugivorous birds have declined. However, Williams (2006) found that blackbirds move many weed seeds, and consequently create plant communities that suit exotic frugivores better than endemic frugivores. Across many sites and native plant species, Kelly et al. (2006) found that blackbirds were numerically unimportant for fruit dispersal. Hence there are two unresolved questions: are blackbirds common or rare visitors to fruit, and do they do more harm than good?

How often blackbirds visit fruits may depend on their local abundance. This appears to be higher in urban areas, both in absolute terms (blackbirds per hectare) and relative terms (blackbirds as a percentage of all frugivorous birds at the site). Van Heezik and Seddon (2012) found 1.4-5.4 blackbirds $\mathrm{ha}^{-1}$ in urban gardens and forest remnants around Dunedin city, and blackbirds were the second or third most abundant bird. Similarly, the New Zealand garden birds survey found blackbirds were the fourth most abundant species (Spurr 2012). However, studies in native forest far from towns found blackbirds to be an order of magnitude less common. In the Department of Conservation nationwide Tier 1 monitoring programme, blackbirds were not in the top five species for birds per ha (MacLeod et al. 2012). Wilson et al. (2014) found blackbird densities of $0.1 \mathrm{ha}^{-1}$ in open to woody habitat in Central Otago, and cite a DOC Tier 1 report as finding similar densities in forest. Similarly, in mature Dacrydium cupressinum forest at Okarito, visual sightings on walked transects found blackbirds to be only the 11 th most common species with 4.6 seen per 100 hours, well behind bellbird (104), silvereye (44), kererū (20), and tūī (17; Spurr et al. 1992). These data suggest that blackbirds are less abundant, both absolutely and relatively, in native forest compared with towns.

The apparent higher density of blackbirds in urban areas should, however, be viewed with caution, as it may be due to differing levels of detectability. This could then lead to underestimates of the role of blackbirds as dispersal agents in non-urban habitats. For example, blackbirds can acclimate to humans and this may explain why they are frequently observed feeding in urban areas (e.g. Burns 2006). In non-urban areas, blackbirds are more wary and this could partly explain the low number of feeding observations by O'Donnell and Dilks (1994), who reported 4270 diet observations for bellbirds, and 2339 for kererū, but only 247 for blackbirds. The data from O'Donnell and Dilks (1994) were included in the review by Kelly et al. (2006) which found blackbirds only making 4\% of visits to native fruits. To what extent blackbirds were rare visitors because they are at low density in native forest, or because they avoid being seen, remains to be determined.

Along with local density and degree of crypsis, the third factor affecting visitation rates is bird feeding preferences. Observations in urban areas (Burns 2012), and faecal analysis in forested areas (Williams \& Karl 1996; this study), confirm that blackbirds and song thrushes are quite generalist and eat many species of plants (Williams 2006). A generalist diet may explain why blackbirds consistently eat more exotic species than native or endemic birds. Where the analysis focuses only on native plant species (e.g. Kelly et al. 2006), the relative importance of blackbirds can be underestimated compared with studies that combine exotic and native plants (e.g. Burns 2012). However, this effect should be modest since even exotic birds still eat a majority of native plants.

Bird feeding preferences will be constrained by gape size. Although blackbirds and song thrushes have the potential to disperse large-seeded native plants, actual evidence of such dispersal is lacking and thus it is difficult to estimate the extent to which these species help disperse large-seeded native plants. There are records of blackbirds feeding on four native plant species with fruits $>10 \mathrm{~mm}$ diameter (Kelly et al. 2010). However, most large-seeded species moved by blackbirds and song thrushes are weeds (Williams \& Karl 1996; Williams 2006; Williams et al. 2010). A comparison can be drawn with brush-tail possums (Trichosurus vulpecula), which are frugivorous and large-bodied (c. $2.5 \mathrm{~kg}$ ) and were said to be potentially important in dispersing seeds (Dungan et al. 2002). But since possums only swallow seeds smaller than c. $10 \mathrm{~mm}$, similar to the limit for silvereyes and bellbirds (Williams et al. 2000), Williams (2003) concluded that possums only disperse 
plants already adequately serviced by silvereyes and bellbirds. The small benefit of possum-mediated dispersal is unlikely to compensate for their known negative impacts through bird predation and vegetation damage.

For blackbirds, although the possible benefits of moving large-seeded native plants are speculative, the damage caused by weed movement is well documented. In Kowhai Bush, all four large-seeded plants moved by blackbirds and song thrushes are weeds. Berberis glaucocarpa is invasive and is spread mainly by these two birds. Invasional meltdown is the process by which exotic species facilitate one another (Simberloff 2006; Simberloff and Von Holle 1999). For example, blackbirds facilitated the spread of Crataegus monogyna at Porters Pass, Canterbury, which accelerated when the first $C$. monogyna trees became large enough to provide blackbird nest sites (Williams et al. 2010). Similar negative links between exotic frugivores and weed spread are common overseas. In Victoria, Australia, introduced blackbirds facilitated the spread of many serious weeds including Chrysanthemoides monilifera, Ligustrum lucidum, Myrsiphyllum asparagoides, Pyracantha coccinea and Schinus molle (Carr 1993). Of 90 major weeds in Hawai'i, $33(37 \%)$ are dispersed by predominantly exotic, frugivorous birds (Simberloff \& Von Holle 1999). The fleshy-fruited tree Myrica faya, in particular, is dispersed by introduced frugivores that have facilitated its spread through Hawaiian forests and disrupted native plant communities (LaRosa et al. 1985). Similarly, the red-whiskered bulbul (Pycnonotus jocosus) is a frugivorous invader that has disrupted plant communities in Réunion by acting as an efficient seed disperser for the invasive Rubus alceifolius (Ian et al. 1991).

In conclusion, exotic blackbirds and song thrushes are generalist frugivores that eat fruits of a wide range of plant species. Both birds are relatively large-gaped, and they have the potential to improve the dispersal of large-seeded native plants. However, this possible benefit has yet to be convincingly demonstrated, and there is evidence that both exotic bird species aid in the spread of weeds. Based on current data, blackbirds and song thrushes appear likely to have a net negative effect on regeneration in New Zealand native forest remnants.

More generally, studies on the contribution of exotic frugivores to fruit dispersal should consider what the frugivores actually do, rather than what they might potentially be capable of doing. Introducing a large-bodied frugivore is unlikely to benefit large-seeded native plants if the frugivore chooses to mainly eat large-seeded weeds.

\section{Acknowledgements}

We thank Environment Canterbury for permission to work in Kowhai Bush, Janice Lord (University of Otago) for access to unpublished fruit size information, Miles Burford (University of Canterbury) for help mist netting birds, the University of Canterbury for accommodation at the Edward Percival Field Station in Kaikoura, the Maori Education Trust for a Queen Elizabeth II Postgraduate Fellowship scholarship to AM, and Anne Gaskett and an anonymous referee for helpful comments on the manuscript.

\section{References}

Alcántara JM, Rey PJ 2003. Conflicting selection pressures on seed size: evolutionary ecology of fruit size in a bird- dispersed tree, Olea europaea. Journal of Evolutionary Biology 16: 1168-1176.

Allen RB, Lee WG 1992. Fruit selection by birds in relation to fruit abundance and appearance in the naturalised shrub Berberis darwinii. New Zealand Journal of Botany 30: 121-124.

Aslan CE, Zavaleta ES, Croll D, Tershy B 2012. Effects of native and non-native vertebrate mutualists on plants. Conservation Biology 26: 778-789.

Atkinson IAE, Millener PR 1991. An ornithological glimpse into New Zealand's pre-human past. Acta XX Congressus Internationalis Ornithologici 1: 129-192.

Bakker JP, Poschlod P, Strykstra RJ, Bekker RM, Thompson K 1996. Seed banks and seed dispersal: important topics in restoration ecology. Acta Botanica Neerlandica 45: 461-490.

Burns KC 2006. A simple null model predicts fruit-frugivore interactions in a temperate rainforest. Oikos 115:427-432.

Burns KC 2012. Are introduced birds unimportant mutualists? A case study of frugivory in European blackbirds (Turdus merula). New Zealand Journal of Ecology 36: 171-176.

Burrows CJ 1994. Fruit, seeds, birds and the forests of Banks Peninsula. New Zealand Natural Sciences 21: 87-87.

Clout MN, Hay JR 1989. The importance of birds as browsers, pollinators and seed dispersers in New Zealand forests. New Zealand Journal of Ecology 12 (Supplement): 27-33.

Clout MN, Lowe SJ 2000. Invasive species and environmental changes in New Zealand. Invasive species in a changing world. Washington, DC, Island Press. Pp. 369-383.

Dobson AT 1979. Vegetation: ecology of Kowhai Bush, Kaikoura. Christchurch, Biological Society, University of Canterbury. Pp. 11-15.

Dungan RJ, O'Cain MJ, Lopez ML, Norton DA 2002. Contribution by possums to seed rain and subsequent seed germination in successional vegetation, Canterbury, New Zealand. New Zealand Journal of Ecology 26: 121-128.

Ferguson RN, Drake DR 1999. Influence of vegetation structure on spatial patterns of seed deposition by birds. New Zealand Journal of Botany 37: 671-677.

Foster JT, Robinson SK 2007. Introduced birds and the fate of Hawaiian rainforests. Conservation Biology 21: 1248-1257.

Garcia D, MartinezD, Stouffer DB, Tylianakis JM2014. Exotic birds increase generalization and compensate for native bird decline in plant-frugivore assemblages. Journal of Animal Ecology 83: 1441-1450.

Green RE 1997. The influence of numbers released on the outcome of attempts to introduce exotic bird species to New Zealand. Journal of Animal Ecology 66: 25-35.

Heather BD, Robertson HA 1998. The field guide to the birds of New Zealand. New York, Oxford University Press. 432 p.

Heck Jr KL, Van Belle G, Simberloff D 1975. Explicit calculation of the rarefaction diversity measurement and the determination of sufficient sample size. Ecology 56: 1459-1461.

Holdaway RN 1999. Introduced predators and avifaunal extinction inNewZealand.In:MacPheeRDEed.Extinctions in near time: causes, contexts, and consequences. New York, Kluwer Academic/Plenum Publishers. Pp. 189-238.

Howe HF 1977. Bird activity and seed dispersal of a tropical wet forest tree. Ecology 58: 539-550.

Hulsman K 1981. Width of gape as a determinant of size of prey eaten by Terns. Emu 81: 29-32. 
Hunt D, Gill B eds 1979. Ecology of Kowhai Bush, Kaikoura. Mauri Ora special publication 2: 7-11.

Hyatt LA, Casper BB 2000. Seed bank formation during early secondary succession in a temperate deciduous forest. Journal of Ecology 88: 516-527.

Kelly D, Ladley JJ, Robertson AW, Anderson SH, Wotton DM, Wiser SK 2010. Mutualisms with the wreckage of an avifauna: the status of bird pollination and fruit-dispersal in New Zealand. New Zealand Journal of Ecology 34: 66-85.

Kelly D, Robertson AW, Ladley JJ, Anderson SH, Mckenzie RJ 2006. The relative (un)importance of introduced animals as pollinators and dispersers of native plants. Biological invasions in New Zealand. Berlin, Springer. Pp. 227-245.

LaRosa AM, Smith CW, Gardner DE 1985. Role of alien and native birds in the dissemination of firetree (Myricafaya Ait.-Myriacaceae) and associated plants in Hawaii. Pacific Science 39: 372-378.

Lee WG, Clout MN, Robertson HA, Wilson JB 1991. Avian dispersers and fleshy fruits in New Zealand. Acta XX Congressus Internationalis Ornithologici 3: 1617-1623.

Levey DJ, Silva WR, Galetti M 2002. Seed dispersal and frugivory: ecology, evolution, and conservation. New York, CABI. 511 p.

MacDonald IAN, Thébaud C, Strahm NA, Strasberg D 1991. Effects of alien plant invasions on native vegetation remnants on La Réunion (Mascarene Islands, Indian Ocean). Environmental Conservation 18: 51-61.

MacFarlane AET 2012. Frugivorous mutualisms in a native New Zealand forest, the good the bad and the ugly. Unpublished M.Sc. thesis, School of Biological Sciences, University of Canterbury, Christchurch, NZ.

MacLeod CJ, Greene TC, MacKenzie DI, Allen RB 2012. Monitoring widespread and common bird species on New Zealand's conservation lands: a pilot study. New Zealand Journal of Ecology 36: 300-311.

McGlone MS 1989. The Polynesian settlement of New Zealand in relation to environmental and biotic changes. New Zealand Journal of Ecology 12: 115-129.

Morton ES 1973. On the evolutionary advantages and disadvantages of fruit eating in tropical birds. American Naturalist 107: 8-22.

O’Donnell CFJ, Dilks PJ 1986. Forest birds in South Westlandstatus, distribution and habitat use. Occasional Publication 10. Wellington, New Zealand Wildlife Service, Department of Internal Affairs. 179 p.

O’Donnell CFJ, Dilks PJ 1994. Foods and foraging of forest birds in temperate rainforest, South Westland, New Zealand. New Zealand Journal of Ecology 18: 87-107.

Poulsen JR, Clark CJ, Smith TB 2001. Seed dispersal by a diurnal primate community in the Dja Reserve, Cameroon. Journal of Tropical Ecology 17: 787-808.

Robertson CJR, Hyvönen P, Fraser MJ, Pickard CR 2007. Atlas of bird distribution in New Zealand 1999-2004. Wellington, Ornithological Society of New Zealand. 533 p.

Sekercioglu CH, Daily GC, Ehrlich PR 2004. Ecosystem consequences of bird declines. Proceedings of the National Academy of Sciences USA101: 18042-18047.

Simberloff D 2006. Invasional meltdown 6 years later: important phenomenon, unfortunate metaphor, or both? Ecology Letters 9: 912-919.

Simberloff D, Von Holle B 1999. Positive interactions of nonindigenous species: invasional meltdown? Biological Invasions 1: 21-32.
Snow B, Snow D 2011. Birds and berries. Calton, UK, T \& AD Poyser. 268 p.

Snow DW 1971. Evolutionary aspects of fruit-eating by birds. Ibis 113: 194-202.

Spurr EB 2012. New Zealand Garden Bird Survey - analysis of the first four years. New Zealand Journal of Ecology 36: 287-299.

Spurr EB, Warburton B, Drew KW 1992. Bird abundance in different-aged stands of rimu (Dacrydium cupressinum) - implications for coupe logging. New Zealand Journal of Ecology 16: 109-118.

Stone CP, Anderson SJ 1988. Introduced animals in Hawaii's natural areas. Proceedings of the Thirteenth Vertebrate Pest Conference: 133-140.

Thompson JN, Willson MF 1979. Evolution of temperate fruit/bird interactions: phenological strategies. Evolution 33: 973-982.

Thorsen MJ, Dickinson KJM, Seddon PJ 2009. Seed dispersal systems in the New Zealand flora. Perspectives in Plant Ecology Evolution and Systematics 11: 285-309.

Thorsen MJ, Seddon PJ, Dickinson KJM 2011. Faunal influences on New Zealand seed dispersal characteristics. Evolutionary Ecology 25: 1397-1426.

Timmins SM, Williams PA 1991. Weed numbers in New Zealand's forest and scrub reserves. New Zealand Journal of Ecology 15: 153-162.

Van Heezik Y, Seddon PJ 2012. Accounting for detectability when estimating avian abundance in an urban area. New Zealand Journal of Ecology 36: 391-397.

Webb CJ, Simpson MJA 2001. Seeds of New Zealand gymnosperms and dicotyledons. Christchurch, NZ, Manuka Press. 428 p.

Wenny DG, Devault TL, Johnson MD, Kelly D, Sekercioglu CH, Tomback DF, Whelan CJ 2011. The need to quantify ecosystem services provided by birds. The Auk 128: 1-14.

Wheelwright NT 1985. Fruit-size, gape width, and the diets of fruit-eating birds. Ecology 66: 808-818.

Williams PA 2003. Are possums important dispersers of large-seeded fruit? New Zealand Journal of Ecology 27: 221-223.

Williams PA 2006. The role of blackbirds (Turdus merula) in weed invasion in New Zealand. New Zealand Journal of Ecology 30: 285-291.

Williams PA, Karl BJ 1996. Fleshy fruits of indigenous and adventive plants in the diet of birds in forest remnants, Nelson, New Zealand. New Zealand Journal of Ecology 20: $127-145$.

Williams PA, Karl BJ, Bannister P, Lee WG 2000. Small mammals as potential seed dispersers in New Zealand. Austral Ecology 25: 523-532.

Williams PA, Kean JM, Buxton RP 2010. Multiple factors determine the rate of increase of an invading non-native tree in New Zealand. Biological Invasions 12: 1377-1388.

Wilson DJ, Norbury G, Walker S 2014. How does woody succession affect population densities of passerine birds in New Zealand drylands. New Zealand Journal of Ecology 38: 257-267.

Young LM 2012. Seed dispersal mutualisms and plant regeneration in New Zealand alpine ecosystems. $\mathrm{PhD}$ thesis, University of Canterbury, Christchurch, New Zealand. 165 p. Available from http://hdl.handle. net/10092/6992.

Editorial board member: Isabel Castro

Received 18 August 2014; accepted 7 April 2015 